\title{
Enhancing Spiritual Palliative Care of Muslim Patients: A Perspective from Islamic Theology
}

Mohammad Manzoor Malik

Lecturer, Department of Philosophy and Religion Graduate School of Human Sciences, Assumption University of Thailand

\author{
DOI: $10.36348 /$ sjnhc.2020.v03i04.001 \\ | Received: 24.03.2020 | Accepted: 31.03.2020 | Published: 07.04.2020 \\ *Corresponding author: Mohammad Manzoor Malik
}

\section{Abstract}

An Islamic approach from its theological sources to address the spiritual pain related to palliative care of terminally ill patients can be established on attaining a spiritual stage of soul or spirit termed as reassured soul. The attainment of such stage is based on hope of the patient to receive mercy and forgiveness of God. And the way of attainment of hope is possible by doing the repentance, praying, and patience. In combating the pain and suffering, the patient is supposed to understand that the life in its reality is a test and facing such a test is possible by two ways, one is patient centric by building patience within to endure the suffering and second is seeking help from God by praying. For the spiritual wellbeing, the patient should understand that his suffering is in fact expiation for his sins. On the other hand, the visitors and caregivers of patients have certain responsibilities that contribute to enhancing of the spiritual well-being of the patient, including comforting them by giving hope to the patients and at the same time praying for their recovery. These all elements enhance the spiritual well-being of patients and help in prevention of suffering by spiritual means.

Keywords: Palliative care, Islam, reassured soul, repentance, expiation.

Copyright @ 2020: This is an open-access article distributed under the terms of the Creative Commons Attribution license which permits unrestricted use, distribution, and reproduction in any medium for non-commercial use (NonCommercial, or CC-BY-NC) provided the original author and source are credited.

\section{INTRODUCTION}

World Health Organization (WHO) defines palliative care as "an approach that improves the quality of life of patients and their families facing the problem associated with life-threatening illness, through the prevention and relief of suffering by means of early identification and impeccable assessment and treatment of pain and other problems, physical, psychosocial and spiritual" [1]. Furthermore, it says that palliative care beside other elements "integrates the psychological and spiritual aspects of patient care" [1]. This article is about spiritual care of such Muslim patients who are terminally ill or face life-threatening illness. The spiritual well-being of the patients has two-fold benefits and aspects: the first one is providing a spiritual relief to patients to cope with the illness and its associated problems such as anxiety, discomfort, and despair, and the second one is helping patients to be spiritually at peace in case there is high certainty that their illness is life-threatening or they are terminally ill.

An Islamic approach from its theological sources to address the spiritual issues concerning the palliative care of the patients with life-threatening illness could be established on a spiritual construct that is attaining a stage of self or soul (nafas) called as reassured soul (nafs-e-mutmainna). The initial state of self (nafas) should be between the fear (khawf) of God and hope (rajja) from God. And to overcome and minimize the element of fear (khawf), the patient should perform repentance (tawbah). On the other hand, the patient while coping with sickness should realize that the reality of life is a test (ibtillah) from God, and facing such test is possible by two ways. The first is the patient centric by building patience (sabar) within to face the sickness and the second is seeking help from God by praying (salat) to him. The test leads to the concept of expiation (kafarah) of the sins and misdeeds. In other words, suffering has a positive meaning in Islam as expiation of sins. On the other hand, there are certain spiritually meaningful responsibilities of caregivers and visitors of patients such as to pray for their healing and giving them hope by saying positive and optimistic words.

In the subsequent parts of this paper, the above arrangement and scheme of the concepts are followed accordingly.

\section{Reassured Soul (nafs-e-mutmainna)}

Attaining reassured soul, the secure self, or the soul at peace (nafs-e-mutmainna) by the end of life is a goal and wish of every Muslim. It is a state of attaining 
peace with and pleasure (rida) of God. The purity of soul and perfection is desired because Muslims believe that they come from God and to him they will return, as The Quran states "Indeed we belong to Allah, and indeed to Him we will return" (The Quran, 2: 156). Furthermore, the life according to the Quran is impermanent therefore a person should be prepare for the hereafter and the "... hereafter is better ..." (The Quran, 87: 16-17) for the believer.

According to The Quran it is the purification of soul that leads to success and it is its corruption that leads to failure as it states "...Truly he succeeds that purifies it (self or soul), and he fails that corrupts it!" (The Quran, 91: 7-10).The Quran describes three stages or types of self (nafas): the soul which commands and encourages doing sin, (nafs-e-ammara), as it is stated in the Quran that this soul "... overwhelmingly commands a person to do sin" [3]. The second type of soul is blaming, or regretting (nafs-e-lawwama). The Quran states that "And I (God) swear by the reproaching soul[3]." It is a guilty soul that eventually leads to shunning the sinful life. The third is reassured soul (nafs-e-mutmainna).

The reassured soul or self (nafs-e-mutmainna) is what a Muslim wishes to attain before death. Regarding this soul, the Quran states that to the righteous it will be said at the time of death, "Oh reassured soul, return to your Lord well pleased, and pleasing to Him[3]." Al-Tabari explains nafs-emutmainna as reassuring, as it is reassured of the promise of God, which he promised the people of faith with of dignity in this world and in the afterlife, and thus the soul ratified it. Ibn Abaas says reassured soul means ratifying self, Qatadah says reassured soul means the believer who reassured himself of the promise of God [4]. This soul is peaceful. At the time of death the angle of death sitting by the side of dying person addresses him by saying, "O pure soul, come out to the forgiveness and pleasure of Allah'. Then his soul comes flowing out like a drop of water flowing from a cup...[5]".

Therefore, it is the perfection of soul or in other words attaining reassured soul that concerns a Muslim patient. And attaining such stage of soul is what matters most in fulfilling spiritual need of a patient in providing relief as the crucial element of the palliative care of a Muslim patient. Muslims believe that after death the body decays but the soul remains and the soul either receives the pleasure and tidings of God or it receives torment and displeasure of God. A righteous soul receives the glad tidings of mercy then it is taken up to heaven and it is said to him "welcome to the good soul that was in a good body. Enter praiseworthy and receive the glad tidings of mercy and fragrance ...[6]."
The state of reassured soul or self (nafas) should be in between the fear (khawf) of God and hope (rajja) from God.

\section{Hope (rajja) and Fear (khawf)}

The best condition and a state of life of a believer in Islam is that he should be living between the fear (khawf) and hope (rajja). He should have fear of God and at the same time he should not be hopeless of his mercy even if one is convinced that he /she has attained the state of reassured soul (nafs-e-mutmainna). There should be balance between fear and hope and this balance keeps a person mindful of his duties and striving for the pleasure of God. The Quran states that "...they call on their Lord, in Fear and Hope... [3]. Therefore, for the reassured soul with which God is pleased is the one that is fearful of God as the Quran states, "... Allah is well pleased with them and they are well pleased with Him; that is for him who fears his Lord"[3].

Though a believer is supposed to be between fear and hope, yet the teachings from the theological sources give higher importance for being hopeful of God's mercy. There is amessage of hope in the Quran, not to be despairing as The Quran states that "O my Servants who have transgressed against their souls! Do not despair of the Mercy of Allah ... [3]. Furthermore, God is with you and will never deprive you of your (good) deeds [3]. The Messenger of Allah said, "Allah the Exalted says: 'I am as my slave expects me to be...". [2]. Therefore, a patient should expect the mercy and forgiveness of God.

To minimize the element of fear and maximize the element of hope, there are certain acts a patient can follow. Among those acts is repentance (taubah) and asking forgiveness (maaf) from people who the patient may have wronged in the past.

\section{Repentance (taubah) and Forgiveness (maaf)}

There is an essential aspect of human beings and that is human imperfection. Just like ordinary human beings, a patient under the palliative care is assumed to have lived with human experience that is imperfect in the sense that such experience may have been comprised of mistakes and sometimes of misdeeds. To gain the spiritual strength, it becomes necessary that such a patient should cleanse himself and feel a spiritual state of purity. Among those acts that can help the patient to cleanse himself is repentance (taubah) and asking forgiveness (maaf) from people who the patient may have wronged in his past.

Repentance (taubah) means that one feels regret for his or her sins and turns to God without any intercession with the intention to obey him. And it is only God who can forgive, The Quran states "Will they not, then, turn towards God in repentance, and ask His forgiveness? For God is much-forgiving, a dispenser of 
grace [3]." and "Hence, ask your Sustainer to forgive you your sins, and then turn towards Him in repentance ..." (The Quran, 11:9). Sheikh Saleh Al - Karbasi explains repentance as the return to the path of God after deviating from it. And repentance can only be achieved by regretting the acts of evil, and by the determination to leave sins and not to return to them, with the seriousness in restoring the rift in the life of human moral because of those sins and by amending the lost rights of people and the rights of God. After all this, if a person sincerely asks forgiveness, God will accept his repentance (https://www.islam4u.com). The Quran states, "But as for those who do bad deeds and afterwards repent and [truly] believe-verily, after such repentance thy Sustainer is indeed much forgiving, a dispenser of grace!" [3].

Therefore, a patient should perform repentance and seek God's forgiveness without any delay before the time of death or while facing a serious illness. Because, "whereas repentance shall not be accepted from those who do evil deeds until their dying hour ..." (The Quran, 4:18). "But as for him who repents after having thus done wrong, and makes amends, behold, God will accept his repentance: ...[3]” “...Verily, God loves those who turn unto Him in repentance and He loves those who keep themselves pure[3]." The above mentioned concept of repentance is comprehensive of repenting the misdeeds a person may have committed by violating the commandments of God and other beings.

However, if a patient has wronged any fellow human being such a patient should ask the person to forgive him. This concept could be called as forgiveness (maaf). The Prophet Mohammad says, "The poor of my Ummah would be he who would come on the Day of Resurrection with prayers and fasts and Zakah but (he would find himself bankrupt on that day as he would have exhausted his funds of virtues) since he hurled abuses upon others, brought calumny against others and unlawfully consumed the wealth of others and shed the blood of others and beat others, and his virtues would be credited to the account of one (who suffered at his hand). ..[7]." By performing repentance (taubah) and seeking forgiveness of persons a patient may have wronged in some way, the patient will gain a spiritual peace. Being at peace with God and fellow human beings.

\section{Test (Ibtilah)}

The concept of test (ibtillah) is connected with worldly life. In Islam, there are tests and trials that a person may face in living his life. Prophet Muhammad said, "If God wants to do good to somebody, He afflicts him with trials[2]." These tests can be in the form of disease, loss of property, danger, hunger etc. In face of these tests, a Muslim whether sick or healthy is supposed to be the best in his conduct and show patience. The Quran states, "And most certainly shall We try you by means of danger, and hunger, and loss of worldly goods, of lives and of [labour's] fruits. But give glad tidings unto those who are patient in adversity [3]." "Every soul shall have a taste of death: and we test you by evil and by good, by way of trial. To us must you return [3]."

The concept of ibtilah (test) shows that a Muslim patient in face of losses, diseases, should have will to live in patience. Thinking that by the best conduct in his adversities he will get reward from God. The Prophet says, "Strange are the ways of a believer for there is good in every affair of his and this is not the case with anyone else except in the case of a believer for if he has an occasion to feel delight, he thanks (God), thus there is a good for him in it, and if he gets into trouble and shows resignation (and endures it patiently), there is a good for him in it[7]."

\section{Patience (sabar) and Prayer (salat)}

In facing adversities, A Muslim patient is supposed to be patient and at the same time, the patient should seek help from God by praying to him. Being patient and at the same time praying enhances the spirituality of the patient and gives him will to live peacefully.

In face of the adversities, a Muslim is supposed to adhere to patience (sabar) and seek help by praying (salat). The Quran states "And seek aid in steadfast patience and prayer: and this, indeed, is a hard thing for all but the humble in spirit[3]". In other place God repeats, "O you who have attained to faith! Seek aid in steadfast patience and prayer: for, behold, God is with those who are patient in adversity [3]." "... and bear in patience whatever [ill] may befall thee...[3]". This patience is going to be fruitful in the hereafter as the Quran states "... reward them for all their patience in adversity [3]". Muslims are supposed to advise each other abiding to patience and mostly when any adversity befalls them and the Quran states "and being, withal, of those who have attained to faith, and who enjoin upon one another patience in adversity, and enjoin upon one another compassion [3]". Besides praying, a Muslim patient should keep repeating the beautiful names of God (zikrullah) "And (all) the Most Beautiful Names belong to God so call on Him by them[3]." because such remembrance of God leads to the peace of heart as the Quran states, "...Verily in the remembrance of Allah do hearts find rest![3]”.

\section{Expiation (Kafarah)}

Kafarah means expiation of sins. According to Islam people will receive reward or punishment according to their deeds either in this world or in hereafter. The punishment is not mechanical that it will necessarily follow by committing a misdeed because God is merciful (Raheem) so he can forgive and his forgiveness cane be sought by seeking and asking is forgiveness (istigfar) by supplications (dua). Furthermore, any harm or sickness that may befall a Muslim is expiation for his sins. And this concept is 
called as Kafarah. It is reported in the Prophetic traditions that whenever the Prophet went to a patient, he used to say to him, "Don't worry, if Allah will, it will be expiation (for your sins....[7]". Furthermore the Prophet said "No calamity befalls a Muslim but that Allah expiates some of his sins because of it, even though it was the prick he receives from a thorn [7]." Similarly, "No fatigue, nor disease, nor sorrow, nor sadness, nor hurt, nor distress befalls a Muslim, even if it were the prick he receives from a thorn, but that Allah expiates some of his sins for that[7]."

Therefore, the above concept of kafrarah is also important to remind a patient that his illness and pain is in fact a spiritual growth for himself so it can make the patient feel better spiritually.

On the other hand, there are certain spiritually meaningful responsibilities of caregivers and visitors of patients such as to pray for their healing and giving them hope by saying positive and optimistic words.

\section{Visiting Sick Person (iyadah al-marid)}

Some of the scholars are of the view that it is an obligatory duty (Sunnah muakkadah) of every person to visit a sick person. However, IbnTaymiyah favored the view that it is a communal obligation (fard kifaayah). Not everybody, but at least some should visit the patient. IbnTaymiya in al-Ikhtiyaaraat holds that it is the correct view (https://islamqa.info/en/answers/71968/visiting-thesick-some-etiquettes). The Prophet said, "Free the captives, feed the hungry and pay a visit to the sick [2]." There are many Prophetic traditions or narrations (ahaadeeth) which speak of its virtue, such as the words of the Prophet (peace and blessings of Allaah be upon him): "When the Muslim visits his (sick) Muslim brother, he is harvesting the fruits of Paradise until he returns [8]." The visitors of the patients are supposed to pray (Duaa) for the sick in the manner as narrated regarding the practice of the Prophet by saying "Don't worry, if Allah will, it will be expiation (for your sins)[2]". It is also narrated that whenever Allah's Messenger paid a visit to a patient, or a patient was brought to him, he used to invoke Allah, saying, "Take away the disease, $\mathrm{O}$ the Lord of the people! Cure him as you are the One Who cures. There is no cure but yours, a cure that leaves no disease" [2]. So the visitors of sick persons are supposed to cheer them up and give them glad tidings of healing, for that will comfort the sick person spiritually. The Prophet is reported to have said "When you enter upon one who is sick, cheer him up and give him hope of a long life, for that does not change anything (of the Divine Decree), but it will cheer the heart of the one who is $\operatorname{sick}[6,9,10] . "$

\section{CONCLUSION}

Handling spiritual pain of Muslim patients in palliative care has necessarily roots in religion. And these roots can be explored only by right understanding of the relevant subject matter from the theological sources. The theological sources lead to a spiritual construct and that is attaining a stage of soul called as reassured soul. The reassured soul as a spiritual construct as explained in the abovementioned discourse consisting of many elements. It includes the concept of hope, repentance, and test, expiation of the sins, patience, and prayer. These all aspects of the construct are patient centered. On the other hand there are responsibilities of care givers and visitors to pray and encourage a patient. The practitioners such as doctors and nurses can and should be part of such spiritual care. They could do so by reminding the patient time to time about how they can be spiritually peaceful. They can enlighten the patient with the wisdom either by themselves or by inviting any Muslim religious person to advise the patient. On the other hand the staff can also advise the visitors before they meet the patient to take the spiritual needs of the patient in consideration.

\section{REFERENCES}

1. World Health Organization. (2012, January 28). WHO | WHO Definition of Palliative Care. Retrieved January 31, 2020, from https://www.who.int/cancer/palliative/definition/en I

2. Al-Bukhari, M. ibn I. al-J. Sahih al-Bukhari. Retrieved from https://quranx.com/hadith/Bukhari/USC-MSA

3. The Quran

4. Al-tabri, M. bin Jarir. (na). Jamie Albayan ean Tawil ay al Quran Tfasir Altiburi). Dar Hijar lil tibaeat wal nashr.

5. Musnad Ahmad ibn Hanbal, h. 17803 in Q\&A, I. (na).(2020). Where Is The Soul, And What Happens To It, After A Person Has Died And Before He Is Buried? Retrieved January 31, 2020, from

https://islamqa.info/en/answers/200530/where-isthe-soul-and-what-happens-to-it-after-a-personhas-died-and-before-he-is-buried

6. Ibn Majah, Imam Muhammad Bib Yazeed AlQazwini. (2007). Sunan Ibn Majah. Houston, Texas: Dar-us-Salam.

7. Al-Hajjaj ibn Muslim, A. A.-H. M. ibn A.-H. ibn M. ibn W. ibn K. A.-Q. A.-Naysabur. (na). Sahih Muslim. Retrieved from https://quranx.com/Hadith/Muslim/USC-MSA/

8. Imam An-Nawawi., I. Y. ibn S. an-Nawawi. (2020). Riyad as-Salihin. Retrieved from https://quranx.com/Hadith/ Riyad as-Salihin /USCMSA/

9. https://www.islam4u.com

10. Q\&A, I. (na).(2020). Visiting the Sick - Some Etiquette. Retrieved January 31, 2020, from https://islamqa.info/en/answers/71968/visiting-thesick-some-etiquettes. 